\title{
Terrorist Demonstration of Islam in Daily News in Riau
}

\author{
Aidil Haris ${ }^{1}$, Syukur Kholil ${ }^{2}$, Lahmuddin ${ }^{2}$ \\ ${ }^{1}$ Muhammadiyah University, Riau \\ ${ }^{2}$ Universitas Islam Negeri Sumatera Utara \\ aidilharis@umri.ac.id
}

\begin{abstract}
Related to the news about the terrorist case, many opinions confirm that Islam is not a terrorist. Islam never teaches violent behavior in state life. Islam remains Islam and terrorists must burn on earth. The problem that happened was that mass media coverage always tended to link Islam and terrorists. To look more deeply at the agenda of media settings in reporting about Islam and Terrorists, researchers want to see this phenomenon in local media in Riau. From the two major media in Riau, namely Riau Pos and Pekanbaru Tribun, researchers studied more deeply about terrorist labeling of Islam through the perspective of critical and ideological studies which eventually gave rise to assumptions about the concept of labeling mass media in the formation of its agenda. So that an important question emerged which was formulated in this study, namely how the label of terrorists against Islam on news about terrorist cases in Tribun Pekanbaru and Riau Pos daily newspapers. This study uses Fairclough CDA model of the procedure for critical discourse analysis whose stages consist of three, namely description, interpretation and explanation. The research methodology in this research uses qualitative research methodology. Qualitative methodology is more intended to express a picture and / or understanding (understanding) about how and why a phenomenon or reality occurs. Based on the results of the research conducted, it can be seen that the west has succeeded in discussing the labeling of Islam as a terrorist religion through mass media. This is evident from the absence of a review by the editors of the media on the meaning of the word terrorist labeled against Islam in every report about terrorists.
\end{abstract}

Keywords : labeling; terrorists; Islam; newspapers

\section{Introduction}

After the collapse of the World Trade Center (WTC) several years ago by a group of 'Hardline Islam', the phobia of Islam emerged in the west. Westerners began to worry and fear the existence of Islam. It is as if they have the view that Islam is a terrorist religion that teaches people to behave in an anarchist manner. By the west, a group of herds "Hardline Islam" was named a terrorist group for committing acts of terror against the security of a country and even the world. Is this a form of discrimination and criminalization of Islam or not?

In Indonesia, cases of attacks carried out by a group of 'Hardline Islam' have also occurred. For example: Bali bombing case involving Amrozi and Imam Samudra as intellectual actors and executors. This is the case with the 2004 bombing of several churches in Indonesia during the Christmas celebration. In the case of the Bali bombings many people were victims of the suicide bombing. This is the case with the tragedy of church bombings in several regions in Indonesia which were carried out simultaneously.

This portrait does not stop there, the mass media also seems to dissolve into a media that exaggerates the attitudes and actions of a group of individuals who committed acts of violence. The deterioration and labels that appear are new icons for Muslims. Not yet known, whether this is an act of labeling or stigma against Islam by the mass media. Or the mass media just dissolves with the fact that it is as if the facts are true events without scenarios from interested groups? 
To look more deeply at the agenda of media settings in reporting about Islam and Terrorists, researchers want to see this phenomenon in local media in Riau. The reason is that some local media in Riau sometimes dissolve by publishing news about terrorist scorching in several regions in Indonesia. The question is whether this act of labeling or stigma against Islam carried out by the local mass media in Riau or just simply dissolving with the facts that occur without digging information behind the actual facts without a scenario from interested groups?.

\section{Literature Review}

\subsection{Labeling and Labeling Theory}

Labeling theory explains deviations especially when the behavior has reached the secondary deviance stage. The deviant definition of re-activist is based also on this labeling theory. In his explanation, labeling theory also uses inter-actionist attitudes that are interested in the consequences of interactions between perverts and ordinary (conventional) societies. This theory does not attempt to explain why certain individuals are attracted or involved in deviant actions, but what is more emphasized is the importance of social definitions and negative social sanctions associated with individual pressures to enter into more deviant actions. Analysis of the labeling is centered on the reactions of others. This means that there are people who give definitions, nicknames, or labels to individuals or actions that according to the person's judgment are negative.

According to labeling theorists, defining deviations is something that is relative and may even be confusing. Because to understand what meaning of deviant behavior. It must be tested through the reactions of others. Therefore, Becker, one of the originators of labeling theory, defines deviation as "the consequences of applying rules and sanctions by others to an offender". ${ }^{2}$

\subsection{Terror Actions Perspective of Conflict Theory}

Will the terrorist group's acts of terror be part of the irregularities and efforts to create conflict? In a Sociology perspective, Conflict Theory focuses more on its analysis on the origin of the creation of rules or social order. This theory does not aim to analyze the origin of violations of rules or the background of a person's deviant behavior. The conflict perspective emphasizes the pluralistic nature of society and the imbalance in the distribution of power that occurs between various groups. The conflict perspective understands the community as groups with various competing interests and will tend to conflict with each other. Through that competition, groups with excessive power will create laws and rules that guarantee their interests are won. ${ }^{3}$

\subsection{Media Agenda Setting and Agenda}

From several assumptions regarding the effects of mass communication, one that survives and develops today considers that mass media by giving attention to certain issues and ignoring others, will have an influence on public opinion. People will tend to know about the things that the media reports on different issues. The main theorizing agenda setting is

\footnotetext{
${ }^{1}$ Setiadi \& Kolip, Pengantar Sosiologi, Cet. 4 (Bandung: Kencana 2015), p. 240

2 Ibid, p. 240

${ }^{3}$ Ibid, p. 243
} 
Maxwell McCombs and Donald Shaw. They wrote that the audience not only studied the news in other matters through the mass media, but also learned how much importance was given to an issue on the topic of the way the mass media placed emphasis on the topic. ${ }^{4}$

\subsection{Terrorism and Jihad (A Psychological Review)}

Terrorism is a phenomenon that is approached by various scientific disciplines, including politics, sociology, psychology, law, criminology and including communication. The problem that often arises later is related to determining the definition of terrorism. According to Mirra Noor Milla in her book entitled Why Choose the Path of Terror? revealed that there was very little agreement between experts in various disciplines in looking at terrorism. ${ }^{5}$

The definition commonly used is the definition formulated by the US government in the 100-20 US Army Field Manual, stability and support operations, namely: terrorism is the use of calculated violence or the threat of violence to produce fear: intended to force or intimidate the government or society in order achievement of goals which are generally political, religious and ideological goals. ${ }^{6}$

\subsection{Mass Media and Terrorism}

The reaction to media coverage for September 9 terrorist activities in the United States, Bali bombings, suicide bombings on the Intifada, violence in Chechnya and several other bombings in Indonesia basically complemented the controversy about who or which party is more worthy of being called a terrorist.

Prajarto said that claims from US allies tended to call terrorism carried out by parties that disrupted US interests. ${ }^{7}$ According to him, on the other hand, the group accused of selfdefense and back accused the United States and its allies of having carried out more "acts" of terrorism. Despite the endless controversy, terrorism today is more easily understood as the action of a group by using violence to create fear to support the group's goals. One of the controversies over media coverage is rooted in questions about mass media as part of or even one of the groups. ${ }^{8}$

\subsection{Islamophobia}

Phobias are considered a special form of fear. De Clerq explained that anxiety in phobias is experienced when someone faces a feared object and situation or in anticipation of facing the condition. In response, people exhibit index behavior which is the main characteristic of all phobias. ${ }^{9}$

According to De Clerq, a group of experts on racial or ethnic relations in the United Kingdom began to form a special commission and study and analyze Islamophobia starting in

\footnotetext{
${ }^{4}$ Nurudin, hal. 184

${ }^{5}$ Mirra Noor Milla. Mengapa Memiliih Jalan Teror: Analisis Psikologis Pelaku Teror, cet.1 (Yogyakarta: Gadjah Mada University Press 2010), hal. 16

${ }^{6}$ Mirra Noor Milla. Mengapa Memiliih Jalan Teror: Analisis Psikologis Pelaku Teror, cet.1 (Yogyakarta: Gadjah Mada University Press 2010), hal. 16

${ }^{7}$ Nunung Prajarto,. "Terorisme dan Media Massa: Debat Keterlibatan Media," Jurnal IImu Sosial dan IImu Politik UGM. Volume 8, Nomor 1, Juli 2004.

${ }^{8}$ Ibid

${ }^{9}$ Moordiningsih. "Islamophobia," Bulletin Psikologi, tahun XII, No. 2, Desember 2004
} 
1995. The commission which examines Muslims in Britain and Islamophobia reports that Islam is perceived as a threat, both in the world and specifically in England. ${ }^{10}$

\subsection{When Islamophobia is a Contemporary Issue}

According to Abdul Aziz in his article entitled "Counteracting Islamophobia through the Reinterpretation of the Koran" mentioning that Islamophobia is one of the contemporary issues that is being intensified. Not only in the Western media, but also not a few media in Indonesia that launched news about Islamophobia. This indicates that in Indonesia it is also "alert" for the existence of Islamophobia. ${ }^{11}$

In his article also discussed about the meaning of Islamophobia. According to him the definition of Islamophobia itself is a combination of the words "Islam" and "phobia".

"Islam as it is known, is essentially a divine religion which in its teachings contains commands and prohibitions to associate other than God (Allah SWT.), Starting from having to practice the pillars of Islam and harmony. While the word "phobia", comes from English "phobia", which means fear, hate. Thus, Islamophobia is an understanding that hates and is afraid of Islam. This fear, because of many things, for example Islam seems to be an extreme religion, war (jihad) and other negative things. In the view of Shafi'i Maarif and Harun Yahya, Alqur an is a book that is in line with the times. He will still be used and needed as an enlightenment (hudan) to provide solutions to the various problems of human life. Understanding Islamophobia usually circulates in the community (someone) who lack knowledge of religion. Due to they are more influenced by a life that is free, liberal, and lacks knowledge of the true teachings of Islam. Therefore, the Islamophobes are usually found more in developed countries, such as Europe and America. Besides being ignorant of the true meaning and teachings of Islam, it is not uncommon because of religious fanaticism. Such as Christianity and Judaism who had hated Islam from the beginning. This reversal of Islamophobia is radical Islam, which also arises due to the reaction of the Islamophobic group. Even these radicalists hate countries that adopt a lot of Islamophobic ideas, like America and the like." 12

\subsection{Radicalism \& Terrorism Motiv in Indonesia}

Discussing terrorism, the stereotype that emerges is a resistance to Islam. According to Zulfadly in his article in the volume journal Akademika 22 No. 01, January-June 2017 entitled; Radicalism and Motivation of Terrorists in Indonesia mention that Radicalism is understood as an inner attitude that reflects beliefs about a truth which is sometimes difficult to understand. This belief about a true one makes the adherents want to realize it in all aspects of life, where life is carried out according to that right. ${ }^{13}$

In his article also stated that radicalism is always associated with political ideology which fights for fundamental changes from an order or system, such as economic, political, social, cultural and educational systems and other aspects of life. As an ideology or political

\footnotetext{
${ }^{10} \mathrm{lbid}$

${ }^{11}$ Abdul Aziz. Counteracting Islamophobia Is through the Reinterpretation of the Qur'an. Jurnal Al A'raf (Jurnal Pemikiran Islam dan Filsafat) IAIN Surakarta. ISSN: 1693-9867 http://ejournal.iainsurakarta.ac.id/index.php/al-araf. 
understanding, radicalism contains a set of ideas or ideas about the shape of society and the state, radicalism also contains strategies and tactics to realize these ideas or ideas. ${ }^{14}$

\subsection{Phenomenon of Terrorism in Indonesia: Study of Aspects of Theology, Ideology and Movement}

In his article Zulfi Mubarak, published in the Islamic Society Study journal, "Salam", the explanation of the word terror, is mentioned by the term system, the regime de terreur which first appeared in 1789 in The Dictionnaire of The Academic Francaise (Marijan, 2003 in Mubarak). ${ }^{15}$ The context of the French revolution is inherent in the use of that term. Therefore, the term terrorism at that time had a positive connotation, namely the actions taken to overthrow the despotic ruler and the actions were successfully carried out. However, the practices of terrorism have long been around since 66-67 BC, when extreme Jewish groups carried out acts of terror, including murder, against the Romans who carried out occupations in their territory (roughly in the disputed territories of Israel and Palestine now). Since then, acts of terrorism in various parts of the world, involving various ethnicities and religions continue to occur. ${ }^{16}$

In Gibbs's view cited by Asfar (2003), the emergence of controversy regarding the definition of terrorism is inseparable from the fact that labeling of acts of terrorism will stimulate strong criticism of the perpetrators. Therefore the effort to define it will not be separated from political or ideological bias. Meanwhile, in Wardlaw's view (1989), efforts to define terrorism cannot be separated from moral problems. This moral problem relates to the reality that in defining terrorism is inseparable from an assessment that there are violent incidents that are justified on the one hand, and there are incidents of violence that are not justified on the other. Therefore, efforts to define terrorism cannot be separated from controversy. ${ }^{17}$

\subsection{Media Construction on the Preaching of Terrorism}

Without a doubt, the mass media is essentially in the middle of a social reality that is full of various interests, conflicts, and facts that are so complex. The media message is not present in the midst of the public, but through a pull mechanism of strong internal and external interests. The agenda presented in the media is not just the actual reality, but a formulation of editorial work that brings back different realities on the face.

\subsection{Terrorism, Radicalism \& Indonesian identity}

In the article entitled Terrorism, Radicalism and Indonesian Identity written by Widyanigrum, et al., It was stated that basically, the symptoms of actions that were charged with violence and triggered conflicts could occur when a love of a particular value system continued to be developed so that it was politically charged. By cornering others for their religious or ethnic ownership, then acts of hatred are actually taking place in the form of resistance and resistance, especially aspects of ideas and institutions that are considered contrary to their beliefs. This form of rejection and fruit of hatred is often the main cause of mass violence. Efforts to strengthen the value system and perspective that refer to a certain

\footnotetext{
${ }^{14} \mathrm{Ibid}$

${ }^{15}$ Ibid

${ }^{16} \mathrm{Ibid}$

17 Ibid
} 
level of ideology will ultimately strengthen the joints of belief in the truth of certain ideologies that are superior to others. ${ }^{18}$

The article also explained that in a pluralistic society where conflicts of interest are subscribed, the value of democracy then becomes the hope for peaceful conflict resolution. In the name of democracy, every human being should ideally get recognition and appreciation for himself. Later democracy is often identified with freedom of expression. Freedom of opinion as a form of self-expression and the right of every human being has become the key in the debate over the practice of radicalism that is increasingly growing in various layers of society. Last radicalism practices are considered the same as the forms of self-expression that are part of Human Rights (HAM). The reason is, when every individual and group has found space for expression, then at this point radicalism begins to enter and is played by certain interest actors. ${ }^{19}$

\section{Research Methodology}

This study uses Fairclough CDA model of the procedure for critical discourse analysis whose stages consist of three, namely description, interpretation and explanation. The research methodology in this research uses qualitative research methodology. Qualitative methodology is more intended to express a picture and / or understanding (understanding) about how and why a phenomenon or reality occurs.

\section{Discussion}

After analyzing media texts, the question that then arises for researchers is how do the media understand the meaning of terrorists? From the search of researchers, it was found that the use of the word terrorist in every constructed reality was nothing more than an informant's statement without giving the literacy to the public about something behind reality.

It must be admitted that as a business industry, the media has subordinated public interests to commercial interests. The media seems trapped in a desire to respond to the mass taste of a group of people (capitalists). J.H. Altschull stated that the market model related to the problem of media confidence includes media should be free from outside interference, the media serves the public's right to obtain information, learn and present the truth, and provide reports fairly and objectively.

The main problem that arises now is that when the concentration of capital ownership in the media industry is getting stronger, media and journalism in it are also threatened to become just business and merchandise. Rupert Murdoch examines how global media business is increasingly corner journalism as a product of merchandise.

Then, what is the labeling of terrorists against Islam on news about terrorist cases in Tribun Pekanbaru and Riau Pos daily newspapers? Based on the results of the analysis that the researchers did, labeling terrorists against Islam did not get recognition and concrete accountability from the editorial ranks. According to the person in charge of page one of Riau Pos, he did not label terrorists in Islam in each of his reports. As is the case with Tribun

\footnotetext{
${ }^{18}$ Anastasia Yuni Widyaningrum, at all. Terorisme, Radikalisme dan Identitas Keindonesiaan. Jurnal Studi Komunikasi. Vol. 2, Ed 1, Maret 2018, p. 32-67

${ }^{19}$ Ibid
} 
Pekanbaru, the Production Manager emphasized that there was no party to label terrorists in Islam. This shows that the writing of the word terrorist in the media is not a labeling given to Islam. However, the media is trapped in western discourse through a group of state elites who try to use the media to roll out meaningful terrorist words in trapping the power of Islam.

The meaning of terrorists understood by the editor of Tribun Pekanbaru and Riau Pos is in line with the meaning expressed by Mirra Noor Milla in her book entitled Why Choose the Path of Terror. According to him terrorists are interpreted as acts of violence, political motives, efforts to produce a broad and systematic atmosphere of fear, and the character of organized action. Based on these five elements, formulated acts of terrorism include: First, the use of violence, force or threat. Second, is political action. Third, it causes intense fear or terror in order to achieve the goal. Fourth, there is an effect of psychological reactions.

The terrorist concept above seems to be a reference for editors to continue to dismantle terrorist cases that have occurred in Indonesia. So it is not wrong if the Production Manager of Alhafis Pekanbaru Tribune, Yasir said that:

"Editors construct events around terrorists into a news product starting from an incident in the form of an act of terror allegedly committed by a person or group suspected of terrorism, such as bomb attacks and the like and attacks on government apparatus, especially lately often targeting members of the police. It could also be the arrest or raid of suspected terrorists. The report came from a reporter's observation at the scene and information from a police spokesman or police chief in the region. "

From the statement it is clear that the basis for the emergence of the word terrorist is because it originates from the statement of the police spokesman, or an event that fulfills some elements of the meaning of terror. Therefore, researchers still respect and appreciate the informant's statement that their media does not label terrorists against Islam, so there is no process of agenda setting to direct the news that corners Islam. However, Riau Pos and Tribun Pekanbaru were trapped (intentionally or unintentionally) into a western scenario (America and its allies) which clearly resisted Islam. So it is feared that the news included in the two mass media becomes a fear (phobia) for many audiences towards Islam.

If it is related to the Agenda setting theory concept, then the opinions of Maxwell McCombs and Donald Shaw have become the foundation of these two media. The rationale for Agenda Setting is that among various topics published by mass media, topics that get more attention from the media will become more familiar to readers and will be considered important in a certain period of time, and will be the opposite for topics that receive less attention from the media.

From the news about terrorists who were developed by Riau Post and Tribun Pekanbaru, it was clear that the media seemed to be ignorant of the various faces of terrorism. For the media, terrorism is terrorism and terrorists are terrorists. Coverage which results in the emergence of psychological fear of criminal offenses is equated with reporting which results in terrorism in the community by blasting and threats of bombing. In addition, the mass media tends to display its coverage of a series of incidents of terrorist acts and consequently the coverage of the motives behind the terrorist group's own attacks and efforts to crush terrorist acts. 


\section{Discourse Developed in the Tribun Pekanbaru and Riau Post Daily Newspapers Regarding the Reporting of Terrorist Cases}

The news about terrorists has succeeded in rolling out the discourse about the figure of the 'jihadist' actor identified with Islam. It is this portrait that ultimately raises the discourse that Islam as a radical religion which ultimately gave birth to the phobia of Islam among ordinary non-Muslims. The fear of a part of the world community towards Islam has not only become a western trap, but this condition has brought about the misunderstanding of people in understanding the concepts and values of a strict Islamic law.

For example, in understanding the meaning of jihad, sometimes which is partially understood Even though the concept of jihad in Islam according to the Quran is:

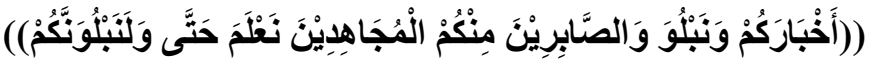

Meaning: "And indeed we really will test you so that we know those who strive and be patient among you, and that we declare (the good and bad) things about you." (Q.S.Muhammad 31)

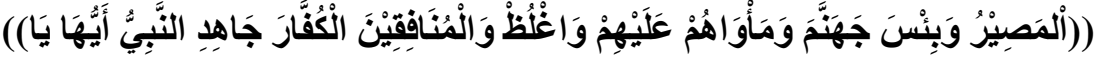

Meaning: "O prophet, strive (against) the unbelievers and the hypocrites, and be strong against them. their place is hell. and that is where the worst returns. "(Q.S.Ataubah 73)

Jihad against the munafiq here is to convey hujah to them and not with the sword as exemplified by Rosul when the hypocrites appear, including Abdullojh bin ubay bin salul. And also based on the hadith of the Prophet:

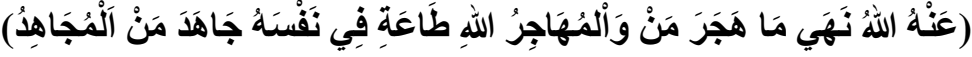

"Mujahids are people who jihad / earnestly obey Allah and those who are hijrah are people who are hijrah from what is forbidden by Allah" (HR Ahmad 6/21, Ibu hibban: 25 and Alhakim and agreed by imam Ad- dzahabi)

From the description of jihad above, it is very clear that jihad does not only have the meaning of war, besides it requires knowledge, practices it, da'wah, fights lust and practices worship to Allah can also be called jihad, if the words of jihad are coupled with pious charity that is.

From several reports presented by the Riau Pos and Tirbun Pekanbaru newspapers, the discourse developed by the two media was more directed at acts of terror carried out by radical groups without labeling the aqeedah that was believed.

\section{Conclussion}

Labeling Terrorists Against Islam On News Regarding Terrorist Cases in the Daily Newspapers of Tribun Pekanbaru and Riau Pos has become a central issue developed by the two mass media. Deliberately or unintentionally, the two mass media are trapped into a western scenario that clearly fights against Islam. So that the labeling included in the two mass media becomes a fear (phobia) for many audiences towards Islam. The discourse developed by the newspaper Tribun Pekanbaru and Riau Pos Daily related the Terrorists was 
more directed at acts of terror carried out by radical groups without labeling aqeedah that was believed.

\section{References}

Badara, Aris. Analisis Wacana (Teori, Metode, dan Penerapannya Pada Wacana Media). Jakarta: Kencana, 2012

Barus, Sedia Willing. Jurnalistik (Petunjuk Teknis Menulis Berita). Jakarta: Erlangga, 2010.

Departemen Agama Republik Indonesia. Al-Quran \& Terjemahan. Semarang: Toha Putra, 1990

Dewabrata, AM. Kalimat Jurnalistik. Jakarta: Kompas, 2004.

Djelantik, Sukawarsini. Terorisme: Tinjauan Psiko-Politis, Peran Media, Kemiskinan dan Keamanan Nasional. Jakarta: Obor, 2010.

Fairclough, Norman. Discourse and Social Change. Cambrige: Polity Press, 2010

Fairclough, Norman. Media Discourse. London: Edward Arnil Hodder Headline Group, 2007

Foucault, Michel. Arekeologi Pengetahuan. Yogyakarta: IRCiSoD, 2012.

Harsono, Andreas. Agama Saya Adalah Jurnalisme. Yogyakarta: Kanisius, 2010.

Jorgensen, Marianne W, Philips, Louise J. Analisis Wacana (Teori dan Metode). Yogyakarta: Pustaka Pelajar, 2007.

Kholil, Syukur. Komunikasi Islam. Bandung: Citapustaka Media, 2007.

Kriyantono, Rachmat. Teknis Praktis Riset Komunikasi. Jakarta: Pranada, 2006.

Mahmud Tahhan, Taysir Mustalah al-Hadis. Beirut: Dar al-Fikr, 1979

Mulyana, Deddy. Komunikasi Massa (Kontroversi, Teori dan Aplikasi). Bandung: Widya Padjajaran, 2008.

Mulyana, Deddy. Pengantar Ilmu Komunikasi. Bandung: Rosdakarya, 2000.

Nasrullah, Rulli. Komunikasi Antar Budaya di Era Siber. Jakarta: Prenada, 2018.

Noor Milla, Mirra. Mengapa Memilih Jalan Teror:Analisis Psikologis Pelaku Teror. Yogyakarta: Gadjah Mada University Press, 2010.

Nuruddin. Citizen Journalism. Jakarta: Rajawali, 2005.

Nurudin. Komunikasi Massa. Malang: Cespur, 2003.

Rohim, Syaiful. Teori Komunikasi. Jakarta: Rineka Cipta, 2009.

Scheechter, Danny. Matinya Media. Jakarta: Obor, 2007.

Setiadi, Elly M \& Kolip, Usman, Pengantar Sosiologi. Bandung: Kencana, 2015

Sugiyono. Metode Penelitian Kualitatif dan Kuantitatif. Bandung: Alfabeta, 2011.

Vivian, John. Teori Komunikasi Massa (Edisi Kedalapan). Jakarta: Kencana, 2008.

\section{Jurnal:}

Abdul Aziz. Menangkal Islamophobia Melalui Reinterpretasi alQuran. Jurnal Al A'raf (Jurnal Pemikiran Islam dan Filsafat) IAIN Surakarta. ISSN: 1693-9867 http://ejournal.iainsurakarta.ac.id/index.php/al-araf.

Anastasia Yuni Widyaningrum, at all. Terorisme, Radikalisme dan Identitas Keindonesiaan. Jurnal Studi Komunikasi. Vol. 2, Ed 1, Maret 2018, page. 32-67

Asri Nuraeni \& Rona Mentari. Komodifikasi Da’i di Televisi: Kajian Ekonomi Politik Media. Jurnal Komunikator, Vo. 5 No. 2 November 2013

Birru, L. (2011) "Indeks Kerentanan Radikalisme" (Online) tersedia: 
Catur Ellyawati, Hetty. Analisis Wacana Kritis Teks Berita Kasus Terbongkarnya Perlakuan Istimewa Terhadap Terpidana Suap Arthalyta Suryani. Jurnal The Massenger Volume III, Nomor 2, Edisi Juli 2011

Eska Nia Sarinastiti dan Nabilla Kusuma Vardhani. Internet dan Terorisme: Menguatnya Aksi Global Cyber-Terrorism Melalui New Media. Jurnal Gama Societa, Vol. 1 No. 1, Januari 2018, $40-52$

Fajar Junaedi. Relasi Teroris dan Media. Jurnal ASPIKOM, Volume 1, Nomor. 01 Tahun 2010

Haris, Aidil. Media Massa: antara Idealisme vs Bisnis (Analisis Framing Pemberitaan Media Lokal di Riau). Jurnal Communicatio Fakultas Ilmu Komunikasi Universitas Muhammadiyah Riau. Vol. 3 No 1. Mei 2012

Hetty Catur Ellyawati, "Analisis Wacana Kritis Teks Berita Kasus Terbongkarnya Perlakuan Istimewa Terhadap Terpidana Suap Arthalyta Suryani”, Jurnal The Massenger Volume III, Nomor 2, Edisi Juli 2011

http://www.voanews.com/indonesian/news/Indeks-Radikalisme-di Indonesia (28 desember 2011).

Ibnu Hamad, Konstruksi Realitas Politik Dalam Media Massa: Studi Pesan Politik Dalam Media Cetak Pada Masa Pemilu 1999, Makara, Social Humaniora, Vol. 8 No. 1, April 2004.

Karomani. Pengaruh Ideologi Terhadap Wacana Berita dalam Media Massa. Mediator, Vol. 5, No. 1 Tahun 2004

Moordiningsih. Islamophobia. Bulletin Psikologi, tahun XII, No. 2, Desember 2004

Mubarok dan Dian Wulandari. Konstruksi Media Dalam Pemberitaan Kontra Terorisme di Indonesia. INFORMASI: Kajian Ilmu Komunikasi ISSN (p) 0126-0650; ISSN (e) 25023837 Vol. 48, No. 1 (2018), pp.139-152. doi: http://dx.doi.org/10.21831/informasi.v48i1.18620

Muhammad Subhan, Pergeseran Orientasi Gerakan Terorisme di Indonesia (Studi Terorime di Indonesia Tahun 2000-2015). Journal of International Relations, Volume 2, Nomor 4, Tahun 2016, hal. 59-67

Nesa Wilda Musfia. Peran Perempuan Dalam Jaringan Terorisme ISIS di Indonesia. Journal of International Relations, Volume 3, Nomor 4, Tahun 2017, hal. 174-180 Online di http://ejournal-s1.undip.ac.id/index.php/jihi

Petsy Jessy Ismoyo, Islamophobia di Perancis: Diskriminasi Perempuan Muslim Maghribi. Jurnal Cakrawala ISSN 16936248.

Prajarto, Nunung. Terorisme dan Media Massa: Debat Keterlibatan Media. Jurnal Ilmu Sosial dan Ilmu Politik UGM. Volume 8, Nomor 1, Juli 2004.

Sri Herwindya Baskara Wijaya. Media dan Terorisme. Jurnal The Messenger, Volume II, Nomor 1, Edisi Januari 2010

Yoyoh Hereyah. Media Massa: Pencipta Budaya Pencerahan yang Menipu Massa (Studi Simulacra dan Hiperrealitas Film Avatar), Jurnal UMN, Vol. 3 No. 2, Desember 2011.

Zufi Mubarak. Fenomena Terorisme di Indonesia: Kajian Aspek Teologi, Ideologi dan Gerakan, Volume 15 Nomor 2 Desember 2012, Jurnal Studi Masyarakat Islam, SALAM

Zulfadly, Radikalisme dan Motiv Teroris di Indonesia, Jurnal Akademika Volume 22 No. 01, Januari-Juni 2017 